\title{
一般口演 3
}

\section{シングルチャンネル筋電図を参照基準とした場合の 睡眠時ブラキシズムの臨床診断 (ICSD3) の正確度}

\author{
Accuracy of clinical diagnostic criteria for sleep bruxism (ICSD3) \\ using a single-channel EMG as a reference standard \\ 三上紗季 ${ }^{1)}$, 山口泰彦 ${ }^{2)}$, 斎藤未來 ${ }^{2)}$, 中島利德 ${ }^{3)}$, 前田正名 ${ }^{2)}$, 齋藤大嗣 ${ }^{2)}$ \\ 佐久間俊光 ${ }^{2}$, 高橋奏多 ${ }^{2}$, 高橋 萌 $^{2)}$, 後藤田章人 ${ }^{1)}$ \\ Saki Mikami ${ }^{1}$, Taihiko Yamaguchi $^{2)}$, Miku Saito ${ }^{2)}$, Toshinori Nakajima ${ }^{3)}$, Masana Maeda ${ }^{2)}$, Taishi Saito $^{2)}$ \\ Toshimitsu Sakuma ${ }^{2)}$, Souta Takahashi ${ }^{2)}$, Mebae Takahashi $^{22}$, Akihito Gotouda $^{1)}$ \\ 1) 北海道大学病院高次口腔医療センター顎関節治療部門 \\ 2) 北海道大学大学院歯学研究院冠橋義歯補綴学教室 \\ ${ }^{3)}$ 北海道大学病院冠橋義歯補綴科 \\ ${ }^{1)}$ Center for Advanced Oral Medicine, Hokkaido University Hospital \\ ${ }^{2)}$ Department of Crown and Bridge Prosthodontics, Faculty of Dental Medicine, Hokkaido University \\ ${ }^{3)}$ Department of Crown and Bridge Prosthodontics, Hokkaido University Hospital
}

\section{I . 目的}

歯科臨床における睡眠時ブラキシズム $(\mathrm{SB})$ の評 価は, 現状では, 問診や臨床所見に委ねられている。 American Academy of Sleep Medicine (AASM) の睡 眠障害国際分類第 3 版（ICSD3）における SB の臨床診 断基準も, 問診と咬耗, 起床時の顎関節や咀嚼筋の症状 の組み合わせによるものであるが，これらの臨床診断の 正確度については不明な点が多い.

そこで本研究では ICSD3の臨床診断の正確度を明ら かにするため, シングルチャンネル携帯型筋電計を参照 基準とした妥当性試験を行った。

\section{II. 方 法}

対象は，ブラキシズムの臨床診断基準（ICSD3）に該 当するブラキサー群 30 名（男性 15 名, 女性 15 名, 平均 年齢 $29.3 \pm 6.9$ 歳）と, 非ブラキサー群 30 名（男性 15 名, 女性 15 名, 平均年齢 $26.7 \pm 12.1$ 歳）とした。本研究は 北海道大学病院自主臨床研究審査委員会の承認を得て 行った。

筋電計は, 超小型コードレス筋電図計測システム
BMS（原田電子工業），データロガータイプ超小型ウエ アラブル筋電困測定システム（原田電子工業），FLA500-SD（フルサワラボ・アプライアンス）のいずれか を用いた。測定部位は, 主咀嚼側の咬筋とし, 装置の設 定は被験者自身が自宅で行った。

記録された筋電図 (EMG) 波形を整流平滑化, $20 \mathrm{~Hz}$ ハイパスフィルタ処理後, 持続時間が $0.25 \mathrm{~s}$ 以上, 振幅 が基線 2 倍以上の波形を抽出した。抽出した波形の最大 振幅を最大随意咬みしめ (MVC) 波形の最大振幅で除 した值を\%MVC 值とした。抽出した基線 2 倍以上の波 形と，5\%，10\%，20\%MVC 以上の波形の睡眠 1 時間 あたりの波形数を算出し，ブラキサー群と非ブラキサー 群間で比較した。統計解析にはマンホイットニ検定を用 い，有意水準は $5 \%$ とした。

参照基準とした EMGによる評価でのブラキサーと非 ブラキサー間の閾值は，過去の論文 ${ }^{2)}$ を参考に，基線 2 倍以上の波形数 $32.2 / \mathrm{h}$ ，ならびに $5 \% \mathrm{MVC}$ 以上の波形 数 $26.4 / \mathrm{h}$ として, 診断の正確度, 感度, 特異度, 陽性 的中率を算出した。 


\section{III. 結果及び考察}

ブラキサー群の睡眠 1 時間あたりの波形数の平均は, 基線 2 倍以上 75.9. $\pm 70.1 ， 5 \% \mathrm{MVC}$ 以上 $72.7 \pm 69.9$, $10 \% \mathrm{MVC}$ 以上 $53.7 \pm 53.5,20 \% \mathrm{MVC}$ 以上 $36.9 \pm 48.5$ で あった。非ブラキサー群は, 基線 2 倍以上 $30.0 \pm 18.0$, $5 \% \mathrm{MVC}$ 以上 $27.9 \pm 17.0,10 \% \mathrm{MVC}$ 以上 $20.3 \pm 14.4$, $20 \% \mathrm{MVC}$ 以上 $10.4 \pm 9.7$ であった。全ての条件におい て, ブラキサー群は非ブラキサー群と比較して有意に大 きな值を示した。

診断の正確度, 感度, 特異度, 陽性的中率は, 基線 2 倍以上の波形数基準では，正診率 $61.7 \%$, 感度 $60.0 \%$, 特異度 $64.0 \%$, 陽性的中率 $70.0 \%, 5 \% \mathrm{MVC}$ 以上の波形 数基準では, 正診率 $66.7 \%$, 感度 $63.2 \%$, 特異度 $72.7 \%$, 陽性的中率 $80.0 \%$ であった。

EMG 波形数は両群で有意差があったが, 図 1 のヒス トグラムの分布からわかるように, 両群間でオーバー ラップする部分が多かった。また， EMG を参照基準と した正確度は低かった。すなわち, 問診と咬耗, 咀嚼筋 や顎関節の症状の組み合わせからなる臨床診断基準を用 いても, SB の識別を正確に行うのは難しいことが示唆 された。

問診と臨床所見を組み合わせた臨床診断の正診率につ いては, Stuginski-Barbosaは, ICSD3の臨床診断の正 確度を睡眠ポリグラフと音声, ビデオ記録を組み合わせ た検査法（PSG-AV）を参照基準として求めたが，高い 正確度は示されていなかった3). PSG-AV はSB 評価の ゴールドスタンダードではあるが，煩雑性と高コストか ら, 被験者を増やすのは難しく, 実際の外来患者に使用 するのは難しかった。そこで, 本研究ではシングルチャ ンネル筋電計による判定を参照基準として, 対象を実際 の外来患者も含め 60 人と増やした研究を行うことがで きた。その結果, 臨床所見による診断の正確度はやはり 高くはないことが確認された。

これらの知見から, SB の臨床診断は簡便でコストが かからないが, 限界があることを理解して診療する必要 性が示唆された。

\section{N. 文献}

1) American Academy of Sleep Medicine. International classification of sleep disorders, third edition. 2014.

2 ) Maeda M, Yamaguchi T, Mikami S, et al. Validity of single-channel masseteric electromyography
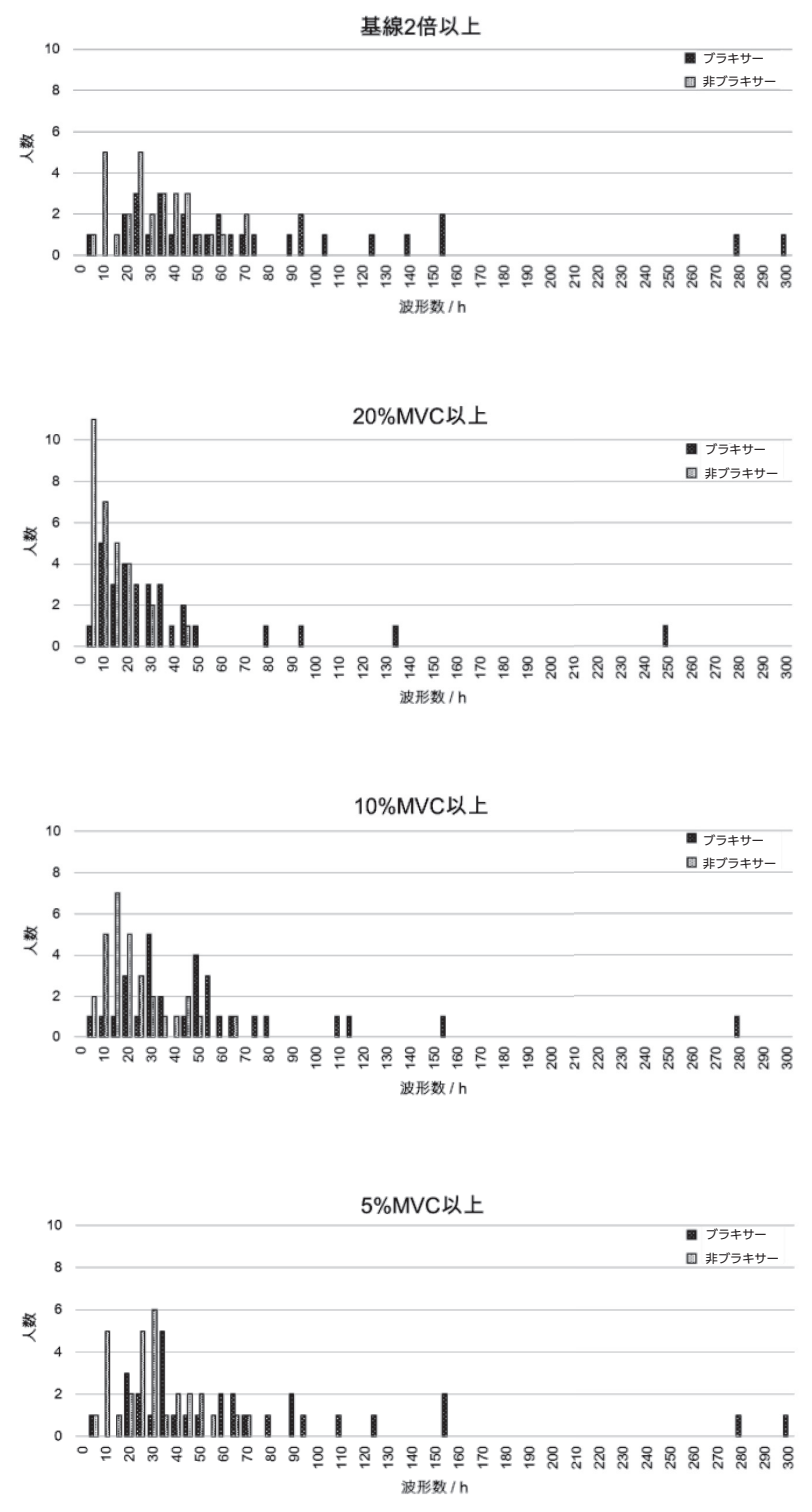

図 11 時間あたりの波形数のヒストグラム

by using an ultraminiature wearable electromyographic device for diagnosis of sleep bruxism. J Prosthodont Res 2019; https://doi. org/10. 1016/j. jpor. 2019. 04.003

3 ) Stuginski-Barbosa J, Porporatti AL, Costa YM, Svensson P, Conti PC. Agreement of the International Classification of Sleep Disorders Criteria with polysomnography for sleep bruxism diagnosis: A preliminary study. J Prosthet Dent 2017; 117: 61-66. 